\title{
Meanings about mothering by women in treatment for drug use
}

\section{Sentidos produzidos sobre a maternagem por mulheres em tratamento por uso de drogas}

\author{
Mariane Capellato MELO \\ Clarissa Mendonça CORRADI-WEBSTER ${ }^{1}$
}

\begin{abstract}
There is a growing number of women who use drugs. Furthermore, the responsibility for family care is still attributed solely to women. This study aimed to describe the meanings constructed regarding mothering by women in treatment for drug use. This qualitative and descriptive study, with a social constructionist intelligibility, was developed with women in treatment at the Centro de Atenção Psicosocial - Álcool e Drogas of Ribeirão Preto, Brazil. Eight life story thematic interviews were carried out. The analysis resulted in four themes: 1) Mothering as the woman's choice; 2) Learning with drug consumption experiences and using this to warn and educate children; 3) Drug consumption interfering in mothering and 4) Drug consumption understood in different ways throughout the treatment. The meanings attributed to mothering consist of moral and gender discourses regarding the responsibilities attributed to women and the difficulties solely attributed to their drug use.
\end{abstract}

Keywords: Family relationships; Substance-related disorders; Women.

\section{Resumo}

É crescente o número de mulheres que consomem drogas. Além disso, ainda se atribui unicamente à mulher a responsabilidade pelo cuidado familiar. Neste estudo, objetivou-se descrever os sentidos construídos a respeito da maternagem por mulheres em tratamento devido ao uso de drogas. Caracteriza-se como um estudo qualitativo, descritivo e exploratório, com inteligibilidade construcionista social. Foi desenvolvido com mulheres em tratamento no Centro de Atenção Psicossocial - Álcool e Drogas de Ribeirão Preto, SP. As oito entrevistas de história de vida temática resultaram em quatro eixos temáticos: 1) Maternagem como escolha da mulher; 2) Experiências do consumo como aprendizado para si e como cuidado/alerta e ensino aos filhos; 3) O consumo de substâncias interferindo na maternagem; e 4) Consumo compreendido de diferentes formas ao longo do tratamento. Os sentidos atribuídos à maternagem são constituídos por discursos morais e de gênero sobre as responsabilidades ditas da mulher e sobre dificuldades consideradas unicamente femininas pelo uso de drogas.

Palavras-chave: Relações familiares; Transtorno relacionado ao uso de substâncias; Mulheres.

$\checkmark \nabla \nabla v$

1 Universidade de São Paulo, Faculdade de Filosofia, Ciências e Letras de Ribeirão Preto, Departamento de Psicologia. Av. Bandeirantes, 3900, Monte Alegre, 14040-901, Ribeirão Preto, SP, Brasil. Correspondência para/Correspondence to: M.C. MELO. E-mail: <marianec@usp.br>.

Article based on the scientific initiation work entitled "Sentidos produzidos sobre a maternagem por mulheres em tratamento para transtornos por uso de substâncias". Universidade de São Paulo, 2013.

Acknowledge: The authors acknowledge Santander for the financial support provided for the development of this project. 
The image of the contemporary woman is constructed by different discourses, dictated throughout our history (Ettorre, 2007). From the eighteenth century, the movement of categorization of the sexes, conducted largely through the biomedical discourse, has taken place intensively, aiming for the domination of the body and thus the regulation of ways of life, determining behavioral repertoires on an axis between normal and deviant (Fabricio, 2004; Foucault, 1988).

The focus on sexual differences has designed the knowledge about the female body and its function in society (Vieira, 2002), outlining that its only vocation, and meaning in life is reproduction (Del Priori, 2011; Soibet, 2011). According to Frasão (2010), there was the valorization of women as mothers, with the care of their children, directed toward the training of the child's physical and moral qualities into adulthood (Frasão, 2010; Vieira, 2002). Thus, the identity of women is defined regarding the attributes of their personality and their behavior, denying the cultural and subjective aspects (Vieira, 2002).

Historically women's rights equality appears linked to the achievement of reproductive rights and the struggle for sexual rights. However, sexual and reproductive hierarchies still exist in our society, which cause mothering to be included in expected standards (race, class, age and partnerships). Therefore, the more women deviate from the normal spectrum, the more they are classified as inferior. This happens, for example, with women/ mothers who are living in situations of disability or mental illness, drug use, offending, and homelessness, etc. Because they are socially circumscribed by identity descriptions that position them as outside the "normal", they will have less access to their rights and will be more socially excluded (Mattar \& Diniz, 2012).

According to Gergen and M. Gergen (2010), the process of identity is social, intersubjective and relational. The various discourses that define normality constitute the multiplicity of possible identity descriptions about people (Burr, 2003). Thus, the socio-historical process that permeates the meanings identity ideal ("normal" mothers), restricting the identity possibilities of women and amplifying factors, such as gender inequality (Mattar \& Diniz, 2012).

When considering the context of drug use, authors point out that the medical literature and the media exploit the image of these women as causing irreparable damage to their children and being unable to exercise care, with them often being labeled as negligent and aggressive (Freire, Padilla, \& Saunders, 2009; Galera, Roldán, \& O'Brien, 2005; Velez et al., 2004). According to Prado and Queiroz (2012), these descriptions justify practices of control over women, still grounded in the care to women as reproducers. In this study, mothering is comprehended as the action of women in caring and educating their children up to adulthood (Carneiro \& Viana, 2008).

The construction of what mothering would be for these women is permeated by different discourses that contribute to a negative view regarding their identity, which becomes socially restricted to that of a drug user, hindering the construction of new roles, such as being a mother. However, according to Hardesty and Black (1999), the role of the mother is not lost because of drug use. The authors also point out that there are many difficulties for women to fulfill their responsibilities as mothers, however, when women who use drugs manage to maintain their habits and provide care for their children, they are valorized by other users.

The constructions regarding women in the context of drug use are located in a historical moment in which drug use is increasing, while simultaneously divisions regarding gender roles are still very present in our society (Ettorre, 2007). Pegoraro and Caldana (2008) highlight the responsibilities that are still placed upon women to take care of the home and family, thus, having an important role in the socialization and family organization and a need to be sober in order to deal with their responsibilities.

A study conducted between 1997 and 2010 with 4,736 patients (716 women) undergoing their first hospitalization for treatment of drug-dependence, highlighted that in 1997, 35 of the 36 women in 
the sample (97.2\%) had a ICD-10 (International Classification of Diseases) diagnosis of F.10 and only 01 (2.8\%) was hospitalized for multiple drug use. In subsequent years there was an increase in women hospitalized due to the multiple drug use diagnosis, and in 2010 the number reached 87 women, 28 of these (32.2\%) hospitalized for alcohol and 59 (67.8\%) for multiple drug use (Moreira, Barbosa, Laranjeira, \& Mitsuhiro, 2014).

In addition to the physical differences, women suffer greater judgment and marginalization, a fact that ultimately impacts on their health conditions, as they have few resources of social support (Galera et al., 2005). This becomes a complicating factor for the identification and approach of female drug users because they tend to hide their consumption for fear of the judgment of health professionals (Yamaguchi, Cardoso, Tores, \& Andrade, 2008). Prado and Queiroz (2012) pointed out that the challenge of working within the substance abuse field is due to being inserted in a space of illegality and making explicit a social group characterized as incapable.

According to Narvaez et al. (2012), drug consumption by women generally begins prior to the formation of a new family. The authors point out that the life story of these women is often marked by restricted parental models, with sexual, physical and emotional victimization, as well as other factors such as psychiatric clinical conditions. Many also experience feelings of loss and low selfesteem, reported due to not having had the chance to give and receive love from the family and being constantly devalued (Galera et al., 2005; Velez et al., 2004).

Women have specific needs of the female world that require recognition by health services (Elbreder, Laranjeira, Siqueira, \& Barbosa, 2008; Oliveira, Paiva, \& Valente, 2006). According to Galera et al. (2005), many are mothers and the dyad relationship is a demonstration of questions about the individuality of the mother and her ability to establish positive bonds. Corradi-Webster (2009) highlighted weaknesses regarding the social network that supports these women in the fulfillment of their roles, with the women often being blamed for failing to perform them.

Considering the points raised in the literature, it can be asked: What meanings do women/mothers that undergo treatment for drug consumption attribute to mothering? How do they experience this function? How do they perceive mothering and the drug consumption? How do they perceive mothering and the treatment? From these questions, this study aimed to describe the meanings produced regarding mothering by women undergoing treatment for drug use. To achieve this aim, a qualitative study using social constructionist intelligibility was conducted, in which women in treatment at a Centro de Atenção Psico Social-Álcool e Drogas (CAPS-ad, Psychosocial Care Center II - Alcohol and Drugs) were interviewed.

\section{Method}

Studies based on social constructionist intelligibility seek to comprehend the processes by which people construct meanings about the world and about themselves, through language (GuanaesLorenzi, Moscheta, Corradi-Webster, \& Souza, 2014). They comprehend that these constructions happen in relationships, due to the influences of the social discourses and life experiences of the person (Gergen, 2009; Guanaes \& Japur, 2003).

In the process of meaning construction, several positions are assumed, resulting in a wide range of possibilities to tell stories about themselves, depending on the context and the interactive moment (Guanaes, 2006). Thus, social constructionist research understands science as a discursive practice, assisting in the opening of possibilities of meaning construction (Gergen \& M. Gergen, 2010; Willig, 2001).

The instrument used was a thematic life story interview script to investigate, together with the women, topics related to the experience of mothering and its relationship with substance consumption and treatment in their life stories (Pegoraro \& Caldana, 2008). The following were used as guiding themes: 1) involvement and care 
provided with mothering; 2) mothering and social support network; 3) mothering and substance consumption; 4) mothering and treatment. With this instrument, used to create a conversational space regarding the subject in question, the intention was to broaden the discussion of mothering by women in treatment for drug use.

Study participants were eight women attending the CAPS-ad of Ribeirão Preto - SP, Brazil, who fulfilled the following criteria for inclusion in the survey: being treated in the selected service during the data collection period; being a woman; having a diagnosis of substance use disorder (abuse or dependence); having and residing with children under 18 years of age. The invitation to the participants was held in the welcome groups for women of the service by one of the researchers.

The interviews took place at the treatment location in a private room, where only the interviewer and the participant remained. The study followed the ethical guidelines for research with human subjects, according to the guidelines of Resolution no 196 of October 10, 1996 (Brazil, 1996), in force during this work period (Process $n^{\circ}$
06695312.9.0000.5407). Furthermore, the interviews took place after the Informed Consent form was signed.

All the interviews were audio recorded. Analysis of these was performed according to the following steps: 1) verbatim transcription of the interviews; 2) exhaustive reading of them; 3) construction of a table containing two columns, with the interview inserted in the first column and the highlighted sub-themes that were related to the study object and were addressed in the reports in the second; 4) examination and reorganization of these sub-themes into thematic axes that gave visibility to the proposed discussion; 5) selection of excerpts from the interview that illustrated the themes; 6) discussion, based on the literature, of the content constructed (Spink, 2010).

\section{Results and Discussion}

In order to characterize the participants, Table 1 was prepared containing some of their characteristics. The participants had a mean age of 30.9 years (Standard Deviation $-S D=7.1$ ) and mean

Table 1

Description of the Participants

\begin{tabular}{|c|c|c|c|c|c|c|}
\hline $\begin{array}{l}\text { Participant } \\
\text { (fictitious name) }\end{array}$ & Age & $\begin{array}{c}\text { Number of children } \\
\text { and age }\end{array}$ & Lived With & $\begin{array}{c}\text { Start of } \\
\text { consumption }\end{array}$ & Drug/Frequency & $\begin{array}{c}\text { Reason for seeking and length of } \\
\text { treatment }\end{array}$ \\
\hline Leticia & 24 & $\begin{array}{c}2 \\
\text { (7 and } 1 \text { years) }\end{array}$ & $\begin{array}{l}\text { Mother and } \\
\text { daughters }\end{array}$ & 14 years & Cocaine (daily) & $\begin{array}{l}\text { To be well to care for daughters ( } 7 \\
\text { days) }\end{array}$ \\
\hline Jane & 28 & $\begin{array}{c}1 \\
\text { (13 years) }\end{array}$ & $\begin{array}{l}\text { Mother, brothers, } \\
\text { husband and son }\end{array}$ & 10 years & $\begin{array}{l}\text { Cocaine ( } 2 \text { capsules } \\
\text { on weekends) }\end{array}$ & Bariatric surgery (122 days) \\
\hline Alexandra & 31 & $\begin{array}{c}1 \\
\text { (15 years) }\end{array}$ & Mother and sister & r 13 years & Crack (daily) & $\begin{array}{l}\text { Concern with what she was doing } \\
\text { to her daughter ( } 21 \text { days) }\end{array}$ \\
\hline Sarah & 31 & $\begin{array}{c}3 \\
(14,13 \text { and } 9 \text { years })\end{array}$ & Children & 15 years & Cocaine (daily) & $\begin{array}{l}\text { To be alive to care for the children } \\
\text { ( } 14 \text { days) }\end{array}$ \\
\hline Andreia & 38 & $\begin{array}{c}3 \\
(16,13 \text { and } 10 \text { years })\end{array}$ & $\begin{array}{l}\text { Husband and } \\
\text { Sons }\end{array}$ & 28 years & Crack (daily) & $\begin{array}{l}\text { Hospitalization in the Intensive } \\
\text { Care Unit, thinking she can not } \\
\text { die and leave her children ( } 61 \text { days) }\end{array}$ \\
\hline Diana & 42 & $\begin{array}{c}1 \\
\text { (16 years) }\end{array}$ & $\begin{array}{l}\text { Mother and } \\
\text { daughter }\end{array}$ & $\begin{array}{l}14 \text { years } / 28 \\
\text { years }\end{array}$ & $\begin{array}{l}\text { Alcohol (not using)/ } \\
\text { Marijuana (daily) }\end{array}$ & $\begin{array}{l}\text { Care of the physical and mental } \\
\text { health ( } 11 \text { years) }\end{array}$ \\
\hline Kate & 33 & $\begin{array}{c}3 \\
(12,8 \text { and } 7 \text { years })\end{array}$ & $\begin{array}{l}\text { Husband and } \\
\text { Sons }\end{array}$ & 12 years & $\begin{array}{l}\text { Alcohol and crack/ } \\
\text { relapse (weekends) }\end{array}$ & $\begin{array}{l}\text { To improve, for her and for the } \\
\text { children (13 years) }\end{array}$ \\
\hline Leandra & 20 & $\begin{array}{c}1 \\
\text { (4 years) }\end{array}$ & $\begin{array}{l}\text { Maternal uncles } \\
\text { and son }\end{array}$ & 12 years & $\begin{array}{l}\text { Cocaine (every } \\
\text { week) }\end{array}$ & $\begin{array}{l}\text { To be able to not worry about the } \\
\text { drug ( } 61 \text { days) }\end{array}$ \\
\hline
\end{tabular}


of 1.9 children $(S D=1.0)$. It was observed that 5 of these did not have a partner in the household, while 1 resided only with her children. The reasons which led them to seek treatment were varied, however, for the majority ( 5 women) the reason appeared directly related to concerns for the children. It should also be noted that the drug use began in childhood and adolescence, with a mean age of onset of consumption of 14.7 (SD = 5.6) years. Regarding the drug used at the time of seeking treatment, 7 reported using cocaine, with 3 of these consuming it in the form of crack. The length of treatment of the women varied, with a minimum time of 7 days and maximum of 13 years.

With the analysis of the data, the following four thematic axes were constructed: 1) Mothering as the woman's choice, constructed from her life experiences; 2) Learning with drug consumption experiences and using this to warn and educate children; 3) Drug consumption and other developments that interfere with mothering; 4) Drug consumption comprehended in different ways throughout the treatment.

\section{Mothering as the woman's choice, constructed from her life experiences}

In this axis, the process of becoming a mother was described as a choice of the woman, being related to her own experiences of being cared for throughout her life. Simultaneously, the experience of being a mother was presented as support for the re-signification of the meanings regarding care, considering the inclusion of the women in a historical context and moment.

In the statement of Alexandra, the perception of having behavior similar to that of her mother was described in a negative way, recognizing her own experiences in her daughter: "I wanted to have a child while at the same time I didn't. So I started doing with my daughter what my mother did with me, rejecting her".

Alexandra described the feeling of rejection regarding the experience as a daughter and highlighted a reproduction of this practice. In the statement of Leandra, the experience as a daughter also appeared as a reference in being a mother, however, it made her reflect and try to construct a different relationship with her son:

There's were lots of things that I didn't have and I felt such a lack, of love, of affection from my mother, I think that I have to give this to him. I think that I can show him that he can trust me, so that when he is going through a problem he can come and open up to me... . Nobody showed me "look you can trust me", so I hid a lot of things, because I was afraid. If, when I started using drugs, I had spoken to my mother maybe today I would be free, but I did not have the courage. Because that was the way it was with my mother.

Faced with this discovery, it was possible to reflect on new ways of being in this mother and child relationship. The literature states that context and family experiences can have great influence on behavior (Galera et al., 2005). The development of a child in environments where there are few resources and little emotional care available can hinder the development of the maternal identity (Bittar \& Nakano, 2011).

However, Alexandra and Leandra, in the experience of being mothers, re-signified the possibilities of the mother and child relationship. Galera et al. (2005) point out that the mother and child relationship refers to the capacity of women to seek and establish positive bonds. Comprehending the need for care for the children can point to establishing positive bonds and can also awaken in these women the desire to reduce or stop using drugs (Hardesty \& Black, 1999). In this study, this is illustrated in Table 1, in which it can be seen that the majority of the women sought treatment motivated by the concern for their children. The statement of Kate highlights this motivation: "Because you think, hey I can't continue this life, I have to stop, if I don't stop for me at least for my children, I have to stop for my children".

The inclusion in a particular historical and cultural moment allows certain constructions, which are guided by meanings seen as natural (Burr, 2003), 
such as the role of the woman in being a mother, as well as the meanings about the woman/mother that is a drug user within a hierarchy that determines what would be an ideal mother (Frasão, 2010; Mattar \& Diniz, 2012). In the statements of the women interviewed, there is their responsibility regarding their own bodies and their children, as they described themselves as responsible for the care of their children, for the difficulties in the relationships with them and even for their own "lack of control".

In the excerpts below, the meanings attributed to mothering are represented by the tasks that the women were responsible to perform, with mothering being a complex task in itself which, added to the meanings and experience of drug consumption, becomes more difficult and fraught with moral values and new duties. The statement of Kate discusses the meanings of being a mother and her responsibilities:

My difficulty is, to take care of the child alone is not easy, you have to be very responsible, to care, everything is on you, but it is good, because it brings much joy, but if we don't have responsibility to care for them... . Because you do not take care of a child just with rice and beans... . Because it's better to give to them than to spend it on drugs, much better.

In addition to the difficulties of mothering without support, it was noted that the majority of the women in this study became mothers and initiated their drug use in their adolescence, a phase of many changes and of great importance in the development (Faúndez, Larraguibel, \& Vinet, 2009).

In the statement of Jane about a patient in treatment, the responsibility for getting pregnant, for the consumption and for the treatment is attributed to the woman, with acquiring control of herself being the solution she highlighted:

The woman only becomes pregnant if she wants to, there are woman who becomes pregnant and blame the boy... . She became pregnant and she started to use crack, it's moment goes there and does it again. It's a question of attitude, it's her thing, she has to organize her life, organize her mind, it's sad that she can't control herself, you know.

Vieira (2002) pointed out that there is a historical construction of the woman as a mother and of her responsibilities to care for the body and the family. In this way, the identity of these women would be marked by the inability to care for themselves and for their children (described many times and commonly as "crack mothers"), making it impossible for resources and positive bonds to also be legitimized.

\section{Learning with drug consumption experiences and using this to warn and educate children}

Substance use and the mothering relationship were linked in the interviews at points such as the relationship between the experience of consumption and its consequences and the care of the children. Thus, as mothers, they could pass on these lessons to their children, promoting a re-approximation with them.

In the following statement, Diana reported that, through her experiences related to drug consumption, she could now warn her child.

He had some problems at school last year, then I went to him and said, I experienced this, I suffered this with my father, I used this, I had trauma and today I don't want you to use this, I can't take it.

In this statement, it can be seen that Diana the mother used what was learned as Diana the user and as a daughter of a user to think about the care of her child. Discussions about the mental health of women point to a series of changes in the family, in which the children are the main people affected, since the care of these is still very limited to the maternal figure, because we live in a society that lacks health policies that provide support for the care of children (Diaz-Caneja \& Johnson, 2004; Pegoraro \& Caldana, 2008). However, some of these discussions position women who have a disorder 
as unfit to care and do not allow discussions in which the experience of the disorder in the mother and child relationship can also lead to the development of the skills of those involved.

The statement of Leticia shows that proximity with the children supports the motivation to continue the treatment: "Today, my daughter was marvelous, I went to pick her up from school yesterday and when she saw me and came 'mummy', she herself realized that I want to change".

The study by Leppo (2012) reports the care of pregnant women who use harm reduction practices out of concern for the fetus. It can be observed in interviews that, even after the pregnancy, the women were still trying to act responsibly for their children and to seek treatment (Table 1) in order to provide care for them, so that they follow different trajectories.

In the statements of Daniele and Leandra, actions of harm reduction for the children were performed, such as avoiding the use of drugs in the presence of the children and during pregnancy. Daniele said:

I live with my children, I just don't do anything right in their sight, they have only seen me drink beer, but I could never use in front of them, and I do not want them to see me as a junkie.

Leandra highlighted that the concern with pregnancy made her interrupt the use, however it was not possible to maintain the interruption after the birth of the child: "When I got pregnant with my son I did not use anything, I thought it was funny that later I restarted the use".

In the interviews, the children provided the motivation for the women to continue in treatment, to perform harm reduction actions for themselves and for the children and to preserve the maternal identity. The mother and child relationship is a possibility for women who use drugs to amplify the descriptions of themselves as more than drug consumers and to follow a trajectory of mothering, as a narrative of change (Radcliffe, 2011).

\section{Drug consumption and other developments that interfere with mothering}

In the narratives, substance consumption was described as interfering with mothering, with the proximity to the children and with the possibilities for the women to see themselves as "good" examples and to exercise maternal authority. The fragile relationship with the children appears as a representation of the consequences of the consumption. Contextual elements that impact in the care of the children and in the consumption of these substances were also described.

In the statement of Andreia, the impact of the substance use in the distancing from her children and from being at home was highlighted:

But I say that they stay away from us, you arrive home, when you go home, it is never the same thing, you come home all dirty, filthy. Sometimes, I even saw the girls going to school, as their father had organized them, I spoke with them, greeted them, but it was never the same thing, you know.

It was observed that despite the participants making use of different drugs (crack, cocaine and marijuana) and using them with various consumption patterns, all of them described the distancing from their children, relating this to the consumption of drugs. Leandra, in one of her statements, described a situation of lack of family support in caring for the child. While striving to maintain this care, including financial, she highlighted the use of the drug as a factor that distanced her from her son:

I am a great mother, but when I take the drug, the drug speaks louder than him, because when I'm with him I am like that, I educate him, I worked a lot because his father could not afford to support him because he also used drugs. Me, even with my addiction I worked more than usual, to support my addiction and sustain him.

One possibility for comprehending drug use by women appears described in the literature as the search for pleasure, reflection of difficulties, of 
not feeling good about themselves and failing to provide care to the children as socially expected (Franco \& Figueiredo, 2004; Radcliffe, 2011). Galera et al. (2005) point out that these women are, in many situations, labeled as negligent and aggressive. These discourses contribute to the construction of moral beliefs, which may cause shame and guilt (Ettorre, 2007). It should be noted that they combine with the lack of public policies to support the woman/mother user of drugs and her family, making it more difficult for women to reconnect to their children and care for them.

In the statements of Alexandra and Leandra family support is mentioned as important in the process of care for the child and the treatment. For Alexandra: "You know, people have relapses, I think it is sad when the family rejects the person, who is not well understood, the person feels frustrated and that's when she starts using".

Franco and Figueiredo (2004), show that women drug users simultaneously experience distancing of the family, abandonment of the partner and lack of employment, housing and food. Therefore, these women often have to cope alone with these emerging situations and need to develop other ways to understand what it is to be a woman and a mother.

Feelings of guilt due to the consumption, the consequences of drug use that affect the children and the distancing are points that need to be considered, because they demonstrate the need for new representations of these women, so they can construct new possibilities to describe themselves, in which the reality in which they live is included.

\section{Drug consumption comprehended in different ways throughout the treatment}

With treatment, the drug consumption began to be described in various ways in addition to the pleasing effect, opening space for new possibilities of interaction and motivation. The perceptions of consumption and mothering are women who sought treatment, among others circumscribers.

In the statements of the participants, it is described that the temporary effect of the drug later leads to problems and pressure that are greater than the initial ones. The statement of Diana illustrates the social pressure regarding the consumption of substances and the "controversies" about using different drugs:

It's what I told you, at the time you say "wow, it's such a great pleasure". You say: "Wow, I feel good". But then after 10 or 15 minutes you come to that reality, the reality of the treatment, but this is a society in which you talk about drink and drink is not prohibited, but it is a drug.

The comprehension of their own consumption and treatment is continually reconstructed, and, thus, other activities can become representative in the lives of these women. The consumption of substances that served as anesthetics can be reevaluated, as well as the comprehension of themselves (Franco \& Figueiredo, 2004). In the statement of Jane, the comprehension of the drug consumption was re-signified and, thus, care was possible and received, in a space of treatment and not judgment:

It was this that helped me, you know, to talk to other people, to say what was happening, I could speak. Because of the fear of people finding out about the problem, that I did not think was a problem, I thought it was just fun and I did not speak to anyone.

It is worth highlighting that while Diana had been in treatment for 11 years, while Jane had only been in it for 4 months, although both reported changes in the way of comprehending the drug consumption after the experience of care in the service. It is clear, therefore, that even shorter treatment helps these women resignify the meaning of the consumption and, thus, think about strategies of change.

Campos and Ferreira (2007) emphasize the importance of the social legitimization of care to 
women, because when they are described as users, they are constituted around the dependency; whereas when they are described as people in treatment, there is an opening of new positions and of the construction of new ways to describe them through the discourses present in the culture and historical moment (Burr, 2003).

The work of the health network encounters, according to Prado and Queiroz (2012), challenges within the field of drug consumption. This is because drug use is also inserted into discourses of illegality and therefore makes explicit a social group characterized as incapable and marginalized. The maternal figure and the children lack health policies that provide support for this context (Diaz-Caneja \& Johnson, 2004) and that consider the specific needs of this phenomenon (Elbreder et al., 2008; Oliveira et al., 2006). The exclusive focus of the treatment on the difficulty and distancing with respect to mothering can make it difficult for the women, who feel that it becomes too "heavy". In addition, these mothers need policies that support better care for the children, before removal from the family environment is necessary.

It should be noted that this study had some circumscribers. One was the inclusion of only women being treated in the CAPS-ad. Female drug users living on the streets may present other characteristics and meanings related to mothering. The same could be the case for women seeking monitoring in religious institutions, in groups or in therapeutic communities. Therefore, studies are suggested that seek to understand the context of mothering for women who are not in treatment or being monitored outside the healthcare services. In addition, this study did not consider the presence of comorbidities in relation to the use of drugs and other diagnoses of mental disorders, therefore, studies are necessary that seek to investigate this experience, which presents other challenges for the mothers and the mental health services. Another circumscriber that should be highlighted refers to the use of only the reports of the women, without knowing how their children experience this relationship. Studies that observe and talk to the mother and child dyad could provide further clarifications about the condition as a whole.

This study showed that treatment was critical due to offering the women a place of acceptance and reflection, so that they could strengthen their bonds. Therefore, the comprehensions regarding their own consumption, mothering and treatment could be continually re-signified, inviting new practices. The growing number of women making use of substances and the consequent impact on their children highlights the need for planning policies that support them and their different requirements. Thus, we think that this is a possible way to construct relationships in which healthier positions, among them being a mother and caregiver, can be used as conducive to new paths of life and descriptions of themselves.

\section{Contributors}

M.C. MELO participated in the preparation of the study design, data collection, tabulation and discussion of the results and preparation of the article. C.M. CORRADI-WEBSTER participated in developing the study design, tabulation and discussion of the results and preparation of the article.

\section{References}

Bittar, D. B., \& Nakano A. M. S. (2011). Violência intrafamiliar: análise da história de vida de mães agressoras e toxicodependentes no contexto da família de origem. Texto \& Contexto - Enfermagem, 20(1), 17-24.

Brasil. Conselho Nacional de Saúde. (1996). Resolução $n^{\circ} 196$, de 10 de outubro 1996. Plenário do Conselho Nacional de Saúde, aprovação das diretrizes e normas regulamentadoras de pesquisas envolvendo seres humanos. Recuperado em abril 21, 2016, de http:// conselho.saude.gov.br/resolucoes/1996/reso196.doc

Burr, V. (2003). Social constructionism (2nd ed.). New York: Routledge.

Campos, G. M., \& Ferreira, R. F. (2007). A importância da legitimação social na (re)construção da identidade de um alcoolista. Estudos de Psicologia (Campinas), 24(2), 215-225. http://dx.doi.org/10.1590/S0103-166X20 07000200008

Carneiro, T. R. Q. S., \& Viana, T. C. (2008). Gestantes portadoras de doenças infecto-contagiosas: preven- 
ção, maternagem e psicanálise. Vita et Sanitas, 2(2), 17-30.

Corradi-Webster, C. M. (2009). Consumo problemático de bebidas alcoólicas por mulheres: discursos e histórias (Tese de doutorado não-publicada). Universidade de São Paulo, Ribeirão Preto.

Del Priori, M. (2011). Magia e medicina na colônia: o corpo feminino. In M. Del Priori. Histórias das mulheres no Brasil (pp.78-114). São Paulo: Contexto.

Diaz-Caneja, A., \& Johnson, S. (2004). The views and experiences of several mentally ill mothers: A qualitative study. Social Psychiatry and Psychiatric Epidemiology, 39(6), 472-482.

Elbreder, M. F., Laranjeira, R., Siqueira, M. M., \& Barbosa, D. A. (2008). Perfil de mulheres usuárias de álcool em ambulatório especializado em dependência química. Jornal Brasileiro de Psiquiatria, 57(1), 9-15. http://dx. doi.org/10.1590/S0047-20852008000100003

Ettorre, E. (2007). Revisioning women and drug use: Gender, power and the body. London: Palgrave MacMillan.

Fabrício, B. F. (2004). Mulheres emocionalmente descontroladas: identidade generificadas na mídia contemporânea. Documento de Estudo em Linguística Teórica e Aplicada, 20(2), 235-263. http://dx.doi.org/10.1590/ S0102-44502004000200003

Faúndez, X., Larraguibel, M., \& Vinet, E. V. (2009). Adolescentes con trastorno por consumo de sustancias: una caracterización de personalidad a través de las normas chilenas del MACI. Revista Médica de Chile, 137(4), 466-474.

Foucault, M. (1988). História da sexualidade l: a vontade de saber. Rio de Janeiro: Graal.

Franco, F. G., \& Figueiredo, M. A. C. (2004). Aids, drogas e "ser mulher". Relatos de mulheres soropositivas para o HIV. Medicina, 37(1/2), 106-116.

Frasão, M. C. G. O. (2010). Saúde é só para a mulher mãe: as políticas públicas em questão [online]. In Fazendo Gênero 9. Diásporas, Diversidade, Deslocamento (pp.1-9). Florianópolis: Universidade Federal de Santa Catarina. Recuperado em maio 25, 2015, de http://www.fazendogenero.ufsc.br/9/resources/anais/ 1278287079_ARQUNO_SAUDEESOPARAAMULHERMAE.pdf

Freire, K., Padilha, P. C., \& Saunders, C. (2009). Fatores associados ao uso de álcool e cigarro na gestação. Revista Brasileira Ginecologia Obstétrica, 31(7), 335-341. http://dx.doi.org/10.1590/S0100-72032009 000700003

Galera, S. A. F., Roldán, M. C. B., \& O’Brien, B. (2005). Mulheres vivendo no contexto de drogas (e violência): papel maternal. Revista Latino-Americana de Enfermagem, 13(N. Esp.), 1142-1147. Recuperado em maio 25, 2015, de http://www.scielo.br/pdf/rlae/v13nspe2/ pt_v13nspe2a07.pdf
Gergen, K. J. (2009). O movimento do construcionismo social na psicologia moderna. Revista Internacional Interdisciplinar Inthertesis, 19(2), 299-320. Recuperado em março 6, 2014, de https://periodicos.ufsc.br/ index.php/interthesis/article/view/1807-1384. 2009v6n1p299/10807

Gergen, K. J., \& Gergen, M. (2010). Construcionismo social: um convite ao diálogo. Rio de Janeiro: Instituto Noos.

Guanaes, C. (2006). O discurso construcionista social. In C. Guanaes. Construção da mudança em terapia de grupo: um enfoque construcionista social (pp.19-52). São Paulo: Vetor.

Guanaes, C., \& Japur, M. (2003). Construcionismo social e metapsicologia: um diálogo sobre o conceito de self. Psicologia: Teoria e Pesquisa, 19(2), 135-143. http:// dx.doi.org/10.1590/S0102-37722003000200005

Guanaes-Lorenzi, C., Moscheta, M. S., Corradi-Webster, C., \& Souza, L. V. (2014). Construcionismo social: discurso, prática e produção do conhecimento. Rio de Janeiro: Instituto Noos.

Hardesty, M., \& Black, T. (1999). Mothering through addiction: A survival strategy among Puerto Rican addicts. Qualitative Health Research, 9(5), 602-619. http://dx.doi.org/10.1177/104973299129122117

Leppo, A. (2012). "Subutex is safe": Perceptions of risk in using illicit drugs during pregnancy. International Journal of Drug Policy, 23(5), 365-373. http://dx.doi. org/10.1016/j.drugpo.2012.01.004

Mattar, L. D., \& Diniz, C. S. G (2012). Hierarquias reprodutivas: maternidade e desigualdades no exercício de direitos humanos pelas mulheres. Interface (Botucatu), 16(40), 107-120. Recuperado em dezembro, 9, 2014, de http://www.producao.usp.br/handle/BDPI/39738

Moreira, M. M., Barbosa, G. L., Laranjeira, R., \& Mitsuhiro, S. S. (2014). Alcohol and crack/cocaine use in women: A 14-year cross-sectional study. Journal of Addictive Diseases, 33(1), 9-14. http://dx.doi.org/10.1080/105 50887.2014.882726

Narvaez, J. C. M., Magalhães, P. V. S., Trindade, E. K., Vieira, D. C., Kauer-Sant'Anna, M., Gama, C. S., ... Kapczinski, F. (2012). Childhood trauma, impulsivity, and executive functioning in crack cocaine users. Comprehensive Psychiatry, 53(3), 238-244. http://dx. doi.org/10.1016/j.comppsych.2011.04.058

Oliveira, J. F., Paiva, M. S., \& Valente C. L. M. (2006). Representações sociais de profissionais de saúde sobre o consumo de drogas: um olhar numa perspectiva de gênero. Ciência \& Saúde Coletiva, 11(2), 473-481. http://dx.doi.org/10.1590/S181232006000200024

Pegoraro, R. F., \& Caldana, R. H. L. (2008). Mulheres, loucura e cuidado: a condição da mulher na provisão e demanda por cuidados em saúde mental. Saúde e 
Sociedade, 17(2), 82-94. http://dx.doi.org/10.1590/S 0104-12902008000200009

Prado, M. A. M., \& Queiroz, I. S. (2012). A emergência da politização da intimidade na experiência de mulheres usuárias de drogas. Estudos de Psicologia (Natal), 17(2), 305-312. http://dx.doi.org/10.1590/S1413-2 94X2012000200015

Radcliffe, P. (2011). Motherhood, pregnancy, and the negotiation of identity: The moral career of drug treatment. Social Science \& Medicine, 72(6), 984-991. http://dx.doi.org/10.1016/j.socscimed.2011.01.017

Soibet, R. (2011). Mulheres pobres e violência no Brasil urbano. In M. Del Priori. Histórias das mulheres no Brasil (pp.362-400). São Paulo: Contexto.

Spink, M. J. (2010). Linguagem e produção de sentidos no cotidiano. Rio de Janeiro: Centro Edelstein de Pesquisas Sociais. Recuperado em maio 25, 2015, de http://www.santoandre.sp.gov.br/pesquisa/ebooks/ 354527.PDF
Velez, M. L., Jansson, L. M., Montoya, I. D., Schweitzer, W., Golden, A., \& Svikis, D. (2004). Parenting knowledge among substance abusing women in treatment. Journal of Substance Abuse Treatment, 27(3), 215-222. http://dx.doi.org/10.1016/j.jsat.2004. 07.004

Vieira, E. M. (2002). A medicalização do corpo feminino. Rio de Janeiro: Fiocruz.

Willig, C. (2001). Introducing qualitative research in psychology: Adventures in theory and method. New York: Open University Press.

Yamaguchi, E. T., Cardoso, M. M. S. C., Torres, M. L. A., \& Andrade A. G. (2008). Drogas de abuso e gravidez. Revista de Psiquiatria Clínica, 35(Supl.1), 44-47.

Received: September 24, 2014

Final version: December 19, 2014

Approved: April 7, 2015 
